\title{
Dok. 3. \\ Posiedzenie rady Europejskiej w Brukseli 11 i 12 grudnia 2008 r. Konkluzje prezydencji
}

Rada Europejska zebrała się w dniach 11 i 12 grudnia $2008 \mathrm{r}$ i zatwierdzila europejski plan naprawy gospodarczej odpowiadajacy okoto 1,5\% PKB Unii Europejskiej (czyli kwocie odpowiadajacej około 200 mld EUR). Plan ten tworzy wspólne ramy działań podejmowanych przez państwa czlonkowskie i przez Unię Europejska, aby zapewnić spójność tych dziatań $i$ w ten sposób zmaksymalizować ich efekty. Rada Europejska osiagnęła także porozumienie w sprawie pakietu energetyczno-klimatycznego, które powinno umożliwić zakończenie prac nad tym pakietem z udziatem Parlamentu Europejskiego do końca roku. To przełomowe porozumienie pozwoli Unii Europejskiej wypetniać ambitne zobowiqzania podjęte w tej dziedzinie w 2007 roku i zachować przewodniq rolę $w$ działaniach na rzecz osiqgnięcia ambitnego i kompleksowego porozumienia ogólnoświatowego w Kopenhadze w przyszlym roku. Rada Europejska wyraziła wole nadania nowego impulsu europejskiej polityce bezpieczeństwa i obrony przez podjęcie konkretnych decyzji w odpowiedzi na nowe wyzwania zwiqzane z bezpieczeństwem. Ponadto Rada Europejska omówiła kwestie majace stanowić odpowiedź na obawy wyrażone w referendum irlandzkim i określila dzialania majace umożliwić wejście w życie traktatu z Lizbony przed końcem 2009 roku.

\section{TRAKTAT Z LIZBONY}

1. Rada Europejska potwierdza traktat $\mathrm{z}$ Lizbony za niezbędny element pozwalający rozszerzonej Unii na działanie w sposób bardziej wydajny, demokratyczny i skuteczny, między innymi na arenie międzynarodowej. Chcąc umożliwić wejście traktatu w życie przed końcem 2009 roku, Rada Europejska, w poszanowaniu celów traktatów, ustaliła następujące kierunki dalszego postępowania.

2. Rada Europejska przypomina, że jeśli chodzi o kwestię składu Komisji, obecnie obowiązujące traktaty wymagają, by w roku 2009 liczba komisarzy została zmniejszona. Rada Europejska postanawia, by - o ile traktat $\mathrm{z}$ Lizbony wejdzie $w$ życie - podjęto, zgodnie z niezbędnymi procedurami prawnymi, decyzję stanowiącą że w skład Komisji nadal będzie wchodzić jeden obywatel z każdego państwa członkowskiego.

3. Rada Europejska z uwagą odnotowała pozostałe kwestie budzące zaniepokojenie narodu irlandzkiego, przedstawione przez premiera Irlandii i zawarte w załączniku 1; wiążą się one z polityką podatkową, kwestiami dotyczącymi rodziny, spraw społecznych i etycznych oraz ze wspólną polityką bezpieczeństwa i obrony w kontekście tradycyjnej irlandzkiej polityki neutralności. Rada Europejska postanawia, że - pod warunkiem iż Irlandia podejmie zobowiązanie przedstawione w pkt 4 - wszystkie niepokojące kwestie przedstawione $\mathrm{w}$ tym oświadczeniu zostaną rozwiązane w sposób satysfakcjonujący zarówno dla Irlandii, jak i dla pozostałych państw członkowskich. Niezbędne gwarancje prawne zostaną zapewnione w odniesieniu do trzech następujących kwestii: 
- żadne postanowienie traktatu z Lizbony nie będzie miało wpływu w odniesieniu do żadnego państwa na zakres ani wykonywanie kompetencji Unii w dziedzinie opodatkowania;

- traktat z Lizbony nie będzie miał wpływu na politykę bezpieczeństwa i obrony państw członkowskich, w tym na tradycyjną irlandzką politykę neutralności, ani na zobowiązania większości pozostałych państw członkowskich;

- fakt przyznania w traktacie z Lizbony prawnego statusu Karcie Praw Podstawowych Unii Europejskiej jak też postanowienia tego traktatu odnoszące się do wymiaru sprawiedliwości i spraw wewnętrznych w żaden sposób nie naruszają żadnych postanowień konstytucji Irlandii dotyczących prawa do życia, edukacji i rodziny. Ponadto potwierdzone zostanie duże znaczenie, jakie nadaje się kwestiom określonym w załączniku 1 lit. d), w tym również prawom pracowniczym.

4. W świetle powyższych zobowiązań Rady Europejskiej, pod warunkiem skutecznego przeprowadzenia do połowy 2009 roku dalszych szczegółowych prac i zakładając, że zostaną one wykonane w sposób satysfakcjonujący, rząd Irlandii zobowiązuje się dołożyć starań, by przed upływem obecnej kadencji Komisji traktat z Lizbony zostal ratyfikowany.

\section{SPRAWY GOSPODARCZE I FINANSOWE}

5. Kryzys gospodarczy i finansowy jest kryzysem światowym. Dlatego Unia Europejska działa w porozumieniu ze swoimi partnerami międzynarodowymi. Na szczycie w Waszyngtonie 15 listopada $2008 \mathrm{r}$. zorganizowanym z jej inicjatywy opracowano ambitny program prac z myślą o uzgodnionym ożywieniu gospodarki światowej, skuteczniejszej regulacji rynków finansowych, wzmocnionym ładzie globalnym i odrzuceniu protekcjonizmu. Program ten należy zrealizować zgodnie z ustalonym harmonogramem. Rada jest proszona o organizację przygotowań tych prac wraz z Komisją i o sporządzenie sprawozdania z postępów tych prac na Radę Europejską wiosną 2009 roku w perspektywie przyszłego szczytu, który odbędzie się 2 kwietnia przyszłego roku w Londynie.

6. Europa określiła w sposób skoordynowany niezbędne środki nadzwyczajne, aby przywrócić dobre funkcjonowanie systemu finansowego i zaufanie podmiotów gospodarczych. Rada Europejska podkreśla, że państwa członkowskie muszą mieć możliwość bezzwłocznego ukończenia prac nad tymi środkami. Wzywa do ich pełnej i szybkiej realizacji z udziałem wszystkich zainteresowanych stron, w ramach wytyczonych przez Radę 2 grudnia 2008 r. Rada Europejska zachęca banki i instytucje finansowe do pełnego wykorzystania narzędzi, które są do ich dyspozycji, w celu podtrzymania i wspierania kredytowania gospodarki, jak i do umożliwienia pożyczkobiorcom skorzystania z obniżek podstawowych stóp procentowych. $Z$ tego względu należy zadbać o to, by środki podejmowane we wspólnych ramach, zwłaszcza mechanizmy gwarancji, byly rzeczywiście stosowane w sposób, który przyczyni się do obniżenia kosztów finansowania ponoszonych przez instytucje finansowe, z korzyścią dla przedsiębiorstw i gospodarstw domowych.

7. Rynki finansowe są wciąż osłabione. Musimy być nadal czujni i dalej wprowadzać na zasadzie priorytetu środki służące wzmocnieniu stabilności sektora finansowe- 
go, nadzoru nad nim i zwiększeniu jego przejrzystości, zwłaszcza środki przewidziane w programie pracy Rady ECOFIN. W tym kontekście Rada Europejska chciałaby, aby negocjacje z Parlamentem Europejskim doprowadziły do szybkiego przyjęcia decyzji prawodawczych, które były przedmiotem podejścia ogólnego Rady. Wzywa także do szybkiego podjęcia decyzji w sprawie innych określonych kwestii priorytetowych, w szczególności w sprawie agencji ratingowych, nadzoru finansowego i standardów rachunkowości.

8. Obecnie kryzys finansowy dotyka gospodarkę. Strefie euro, a nawet całej Unii, grozi recesja. W tych wyjątkowych okolicznościach Europa będzie działać w sposób jednolity, silny, szybki i zdecydowany, aby uniknąć spirali recesji i wesprzeć działalność gospodarczą i zatrudnienie. Skorzysta ze wszystkich instrumentów, którymi dysponuje, i będzie działać w sposób skoordynowany, tak aby zmaksymalizować efekty środków podejmowanych przez Unię i przez każde państwo członkowskie. W tym kontekście kluczową rolę mają również do odegrania polityki państw członkowskich w zakresie ochrony społecznej i włączenia społecznego.

9. Rada Europejska wyraża zgodę na europejski plan naprawy gospodarczej opisany poniżej. Plan ten będzie stanowić spójne ramy działań, które mają być podjęte na szczeblu Unii, jak i środków, o których decydują poszczególne państwa członkowskie w zależności od sytuacji w każdym z nich. W duchu komunikatu Komisji z dnia 26 listopada 2008 r. plan ten wiąże się z nakładami odpowiadającymi łącznie około 1,5\% PKB Unii Europejskiej. Przewiduje on również podjęcie działań priorytetowych mających na celu przyspieszenie dostosowania naszych gospodarek do obecnych wyzwań.

10. W tym kontekście Europejski Bank Centralny i pozostałe banki centralne znacznie obniżyły swoje stopy procentowe; tym samym wspierają wzrost, który nie stanie się źródłem inflacji, i przyczyniają się do stabilności finansowej.

1 Projekty dyrektyw w sprawie wymogów dotyczących funduszy własnych banków, w sprawie wypłacalności zakładów ubezpieczeniowych, w sprawie przedsiębiorstw zbiorowego inwestowania $\mathrm{w}$ zbywalne papiery wartościowe i $\mathrm{w}$ sprawie systemów gwarancji depozytów.

11. Jeżeli chodzi o działania Unii Europejskiej, Rada Europejska popiera w szczególności:

- zwiększenie kwoty, jaką Europejski Bank Inwestycyjny przeznacza na interwencje 30 mld EUR w okresie 2009-2010 - zwłaszcza na rzecz małych i średnich przedsiębiorstw, energii ze źródeł odnawialnych i ekologicznego transportu, w szczególności na rzecz sektora motoryzacyjnego, a także utworzenie europejskiego funduszu na rzecz energii, zmian klimatycznych i infrastruktury 2020 („fundusz Marguerite”) we wspólpracy z krajowymi inwestorami instytucjonalnymi;

- uproszczenie procedur i przyspieszenie realizacji programów finansowanych przez Fundusz Spójności, fundusze strukturalne lub Europejski Fundusz Rolny na rzecz Rozwoju Obszarów Wiejskich z myślą o wzmocnieniu inwestycji infrastrukturalnych oraz inwestycji na rzecz efektywności energetycznej; na podstawie wykazu konkretnych projektów, który zostanie przedstawiony przez Komisję, z uwzględnieniem odpowiedniego rozkładu geograficznego, uruchomienie środków umożliwiających - w ramach budżetu wspólnotowego - zwiększenie inwestycji w tych sektorach 
i rozwój szerokopasmowego Internetu za pośrednictwem zachęt regulacyjnych, także w strefach o słabo rozwiniętej infrastrukturze;

- szybkie rozpoczęcie przez Europejski Fundusz Społeczny uzupełniających działań służących wsparciu zatrudnienia, zwłaszcza na rzecz ludności w najtrudniejszym położeniu, ze zwróceniem szczególnej uwagi na najmniejsze przedsiębiorstwa, zmniejszając pozapłacowe koszty pracy;

- mobilizację na rzecz zatrudnienia w kluczowych sektorach gospodarki europejskiej, w szczególności za pomocą europejskiego funduszu dostosowania do globalizacji, w tym dzięki udoskonaleniu i przyspieszeniu jego procedur;

- możliwość stosowania przez państwa członkowskie, które wyrażą takie życzenie, obniżonych stawek VAT w pewnych sektorach; Rada Europejska zwraca się do Rady ECOFIN o rozwiazanie tej kwestii do marca 2009 roku;

- dwuletnie zwolnienie powyżej progu de minimis w kwestii pomocy państwa w przypadku kwot nieprzekraczających 500000 EUR i dostosowanie ram niezbędne do zwiększenia wsparcia dla przedsiębiorstw, w szczególności MŚP, a także pełną realizację planu działania na rzecz programu Small Business Act przyjętego przez Radę 1 grudnia $2008 \mathrm{r}$.

- wykorzystanie w latach 2009-2010 przyspieszonych procedur zawartych w dyrektywach w sprawie zamówień publicznych, co jest uzasadnione wyjątkowym charakterem bieżącej sytuacji gospodarczej, w celu skrócenia z 87 do 30 dni czasu trwania procedur przetargowych najczéściej stosowanych w odniesieniu do głównych projektów publicznych;

- dalsze ogólne i znaczne zmniejszenie obciążeń administracyjnych przedsiębiorstw. Rada Europejska zwraca się do Parlamentu Europejskiego, Rady i Komisji o jak najszybsze przyjęcie niezbędnych decyzji, w tym w stosownym przypadku dotyczących ram regulacyjnych, w pełnym poszanowaniu obecnej perspektywy finansowej i procedur zawartych w porozumieniu międzyinstytucjonalnym, w jak najkrótszym terminie.

12. Ze swojej strony państwa członkowskie przedsięwzięły już pewną liczbę ważnych środków dostosowanych do ich indywidualnej sytuacji i pozostawiających różne pola manewru. Mając na uwadze skalę kryzysu, niezbędne są zwiększone i skoordynowane działania w ramach wspólnego podejścia w oparciu o następujące wytyczne:

- środki wsparcia popytu muszą mieć na celu skutki natychmiastowe, być ograniczone w czasie i być ukierunkowane na sektory najbardziej dotknięte kryzysem i najważniejsze z punktu widzenia struktury gospodarki (np. sektor motoryzacyjny i budowlany);

- środki te moga przyjąć formę - w zależności od sytuacji poszczególnych państw wzrostu wydatków publicznych, rozsądnych redukcji obciążeń podatkowych, obniżenia składek na ubezpieczenie społeczne, szczególnych form wsparcia dla niektórych kategorii przedsiębiorstw lub pomocy bezpośredniej dla gospodarstw domowych, zwłaszcza tych, które znajdują się w szczególnie trudnej sytuacji;

- będą im towarzyszyć zwiększone starania w zakresie wdrożenia reform strukturalnych w ramach strategii lizbońskiej. Reformy te będą się koncentrować na zwiększonym finansowaniu inwestycji i infrastruktury, poprawie konkurencyjności przedsiębiorstw, 
większym wsparciu dla MŚP i promowaniu zatrudniania pracowników, innowacji, badań i rozwoju oraz edukacji i szkoleń.

13. Rada Europejska podkreśla, że zmieniony pakt stabilności i wzrostu pozostaje fundamentem budżetowych ram UE. Zapewnia on elastyczność umożliwiającą wdrożenie ogółu środków przewidzianych w planie naprawczym. Mając świadomość, że środki te tymczasowo pogłębią deficyty, Rada Europejska potwierdza swoje pełne zaangażowanie na rzecz zrównoważonych finansów publicznych i wzywa państwa członkowskie do jak najszybszego wznowienia realizacji średniookresowych celów budżetowych zawartych w pakcie, w miarę poprawy sytuacji gospodarczej.

14. W obecnych okolicznościach stosowanie przez Komisję zasad konkurencji również powinno odpowiadać wymogom szybkiego i elastycznego działania. W tym kontekście Rada Europejska z zadowoleniem odnosi się zwłaszcza do przyjęcia przez Komisję nowych wytycznych dla instytucji finansowych i apeluje o ich szybkie wdrożenie.

15. Rada Europejska jest przekonana, że ten ambitny plan naprawczy, zbieżny z podobnymi inicjatywami realizowanymi przez inne główne gospodarki światowe, $\mathrm{w}$ decydujący sposób przyczyni się do szybkiego powrotu gospodarki europejskiej na drogę wzrostu i tworzenia miejsc pracy. Począwszy od posiedzenia w marcu 2009 roku Rada Europejska będzie dokonywać oceny realizacji planu naprawy, a w razie potrzeby będzie mogła go uzupełniać lub dostosowywać.

16. Rada Europejska wzywa Radę i Komisję do podjęcia dialogu z państwami produkującymi węglowodory w celu znalezienia środków trwałej stabilizacji cen energii.

17. Rada Europejska zgadza się z celem polegającym na tym, by w tym roku na forum Światowej Organizacji Handlu osiagnacć porozumienie w sprawie warunków, które pozwolą na zakończenie dauhańskiej agendy rozwoju w sposób ambitny, globalny i zrównoważony.

18. Europa musi dalej inwestować w swoją przyszłość. Zależy od tego jej dobrobyt w przyszłości. Rada Europejska apeluje o uruchomienie europejskiego planu na rzecz innowacji, w połączeniu z rozwojem europejskiej przestrzeni badawczej i z refleksją na temat przyszłości strategii lizbońskiej po roku 2010, obejmującego wszystkie warunki zrównoważonego rozwoju i podstawowe technologie przyszłości (w szczególności energie, technologie informacyjne, nanotechnologie, technologie kosmiczne i związane z nimi usługi, nauki biologiczne).

\section{ENERGIA I ZMIANY KLIMATYCZNE}

19. Rada Europejska z zadowoleniem przyjmuje wyniki prac prowadzonych z Parlamentem Europejskim w ramach procedury współdecyzji, które pozwoliły na osiaggnięcie szerokiego porozumienia co do zasady w sprawie zasadniczej części czterech wniosków składających się na energetyczno-klimatyczny pakiet prawodawczy. $Z$ zadowoleniem przyjmuje również fakt, że osiągnięte zostało całkowite porozumienie w sprawie wniosków prawodawczych dotyczących emisji $\mathrm{CO}_{2}$ pochodzącej z lekkich pojazdów samochodowych, jakości paliw oraz dyrektywy o odnawialnych źródłach energii. 
20. Rada Europejska omówiła kwestie wdrożenia pakietu oraz kwestie wciąż nierozstrzygnięte. Osiagnęła porozumienie w sprawie elementów przedstawionych w dokumencie 17215/08.

21. Rada Europejska wzywa Radę, aby w związku z powyższym dążyła do porozumienia z Parlamentem Europejskim, tak aby umożliwić przed końcem roku osiagnięcie porozumienia $\mathrm{w}$ sprawie całego pakietu w pierwszym czytaniu.

22. Pakiet ten zapewni realizację ambitnych zobowiązań w dziedzinie energii i klimatu podjętych przez Unię Europejską w marcu 2007 roku i marcu 2008 roku, w szczególności realizację celu zakładającego obniżenie emisji gazów cieplarnianych o 20\% w 2020 roku. Rada Europejska potwierdza zobowiązanie Unii Europejskiej do zwiększenia skali redukcji do $30 \% \mathrm{w}$ ramach ambitnego i kompleksowego porozumienia ogólnoświatowego w Kopenhadze w sprawie zmian klimatycznych, obejmującego okres po roku 2012, pod warunkiem że pozostałe kraje rozwinięte zobowiążą się do osiągnięcia porównywalnych redukcji emisji i że bardziej zaawansowane gospodarczo kraje rozwijające się wniosą wkład dostosowany do ich odnośnych obowiązków i możliwości.

23. W marcu 2010 roku Komisja przedstawi Radzie Europejskiej szczegółową analizę wyników prac konferencji kopenhaskiej, w tym w sprawie przejścia od redukcji o $20 \%$ do redukcji o $30 \%$. Rada Europejska przystapi na tej podstawie do oceny sytuacji, w tym skutków na konkurencyjność europejskiego sektora przemysłowego i innych sektorów gospodarki.

24. W kontekście tego porozumienia i planu naprawy gospodarczej niezbędna jest intensyfikacja działań z myślą o poprawie efektywności energetycznej budynków i infrastruktury energetycznej, promowaniu produktów ekologicznych oraz wspieraniu starań podejmowanych przez sektor motoryzacyjny zmierzających do produkowania pojazdów bardziej przyjaznych środowisku.

25. Starania Unii na rzecz powstrzymania zmian klimatycznych idą w parze ze zdecydowanymi działaniami służącymi zwiększeniu bezpieczeństwa energetycznego, w tym działaniami w zakresie mostów energetycznych i działaniami na rzecz przyłączenia krajów najbardziej odizolowanych od europejskiej sieci. Z tego względu Rada Europejska wzywa Radę, by na podstawie wytycznych określonych w jej konkluzjach z października 2008 roku, przeprowadziła szybką analizę planu działania w sprawie bezpieczeństwa energetycznego i solidarności energetycznej, przedstawionego przez Komisję, z myślą o posiedzeniu Rady Europejskiej w marcu 2009 roku.

\section{WSPÓLNA POLITYKA ROLNA}

26. Rada Europejska podkreśla wagę porozumienia osiagnniętego w Radzie w sprawie oceny funkcjonowania reformy WPR.

27. Rada Europejska wyraziła poparcie dla działań podjętych przez Irlandię w obliczu sytuacji na rynku wieprzowiny, a także dla szybko podjętych przez to państwo środków ostrożnościowych. Zwraca się do Komisji, by udzieliła wsparcia rolnikom i rzeźniom w Irlandii, współfinansując środki konieczne do usunięcia odpowiednich zwierząt i produktów z rynku. 


\section{STOSUNKI ZEWNĘTRZNE ORAZ EUROPEJSKA POLITYKA BEZPIECZEŃSTWA I OBRONY}

\section{Europejska polityka sąsiedztwa}

28. Rada Europejska zatwierdza wytyczne wynikające z posiedzenia ministerialnego, które odbyło się w Marsylii w dniach 3-4 listopada 2008 r.; wytyczne te pozwoliły doprecyzować zasady funkcjonowania Unii dla Śródziemnomorza. Apeluje, w ramach wprowadzonych w ten sposób struktur, o kontynuowanie ambitnej realizacji tej inicjatywy we wszystkich jej wymiarach.

29. Podobnie partnerstwo wschodnie pozwoli w istotny sposób wzmocnić politykę UE wobec wschodnich partnerów europejskiej polityki sąsiedztwa (Armenia, Azerbejdżan, Białoruś, Gruzja, Republika Mołdowy, Ukraina) w aspekcie dwustronnym i wielostronnym; będzie również uzupetnieniem innych rodzajów współpracy prowadzonej już z państwami sąsiadującymi z Unią, takich jak synergia czarnomorska, którą będzie trzeba uwzględniać. Partnerstwo wschodnie powinno pomóc krajom partnerskim w dokonywaniu postępów w procesie reform, przyczyniając się tym samym do ich stabilności i zbliżenia z UE. Rada Europejska z zadowoleniem przyjmuje wnioski przedstawione przez Komisje w komunikacie z 3 grudnia 2008 r. i zobowiązuje Radę do ich przeanalizowania i do złożenia jej sprawozdania, tak by na posiedzeniu w marcu 2009 roku mogła zatwierdzić tę ambitną inicjatywę $i$ by partnerstwo wschodnie zostało uruchomione na jednym ze szczytów z krajami partnerskimi zorganizowanych przez nadchodzącą prezydencję czeska.

\section{Europejska polityka bezpieczeństwa i obrony}

30. Rada Europejska chciałaby - poprzez załączone oświadczenie - nadać nowy impuls europejskiej polityce bezpieczeństwa i obrony. W poszanowaniu zasad Karty Narodów Zjednoczonych i decyzji Rady Bezpieczeństwa ONZ polityka ta nadal będzie się rozwijać w pełnej komplementarności z działaniami NATO w ramach uzgodnionego partnerstwa strategicznego między UE a NATO i w poszanowaniu ich niezależności w podejmowaniu decyzji i ich procedur. W tym celu Rada Europejska przychyla się do analizy sprawozdania z realizacji europejskiej strategii bezpieczeństwa z 2003 roku i zatwierdza oświadczenia przyjęte przez Radę, które uzgadniają nowe cele, aby wzmocnić i zoptymalizować europejskie zdolności w najbliższych latach, i podkreślają gotowość UE do działania na rzecz międzynarodowego pokoju i bezpieczeństwa oraz faktycznego zapewnienia bezpieczeństwa swoim obywatelom.

Załącznik 1

\section{OŚWIADCZENIE WYSZCZEGÓLNIAJĄCE KWESTIE BUDZĄCE ZANIEPOKOJENIE NARODU IRLANDZKIEGO ZWIĄZANE Z TRAKTATEM Z LIZBONY, PRZEDSTAWIONE PRZEZ PREMIERA IRLANDII}

a) Dopilnowanie, by spełnione zostały wymogi Irlandii dotyczące utrzymania jej tradycyjnej polityki neutralności; 
b) Dopilnowanie, by postanowienia traktatu z Lizbony nie wpłynęły na dalsze stosowanie przepisów konstytucji Irlandii o prawie do życia, o edukacji i o rodzinie;

c) Dopilnowanie, by traktat z Lizbony nie skutkował wprowadzeniem jakichkolwiek zmian w odniesieniu do zakresu lub wykonywania kompetencji Unii w dziedzinie opodatkowania;

d) Potwierdzenie, że Unia przywiązuje wielką wagę do:

- postępu społecznego i ochrony praw pracowniczych;

- usług publicznych, jako niezbędnego instrumentu zapewniającego spójność społeczną i regionalną;

- odpowiedzialności państw członkowskich za świadczenie usług edukacyjnych i zdrowotnych;

- zasadniczej roli i szerokiego zakresu uprawnień organów krajowych, regionalnych i lokalnych w zakresie świadczenia, zlecania i organizowania usług niemających charakteru gospodarczego świadczonych w interesie ogólnym, na które nie będą miały wpływu żadne postanowienia traktatu z Lizbony, w tym postanowienia dotyczące wspólnej polityki handlowej.

\section{OŚWIADCZENIE RADY EUROPEJSKIEJ. TRAKTAT Z LIZBONY - ŚRODKI PRZEJŚCIOWE DOTYCZĄCE PREZYDENCJI RADY EUROPEJSKIEJ I PREZYDENCJI RADY DO SPRAW ZAGRANICZNYCH}

Jeżeli traktat $\mathrm{z}$ Lizbony wejdzie w życie w momencie, gdy półroczna prezydencja Rady już się rozpocznie, Rada Europejska - chcąc uwzględnić prace przygotowawcze i zapewnić harmonijny przebieg prac - ustala następujące środki przejściowe:

- właściwe organy państwa członkowskiego sprawującego w tym czasie półroczną prezydencję Rady będą do końca danego półrocza nadal przewodniczyć wszystkim posiedzeniom Rady i Rady Europejskiej oraz posiedzeniom z udziałem państw trzecich;

- państwo członkowskie obejmujące półroczną prezydencję Rady w następnej kolejności będzie miało za zadanie podjąć w tym półroczu konkretne konieczne środki związane z organizacyjnymi i merytorycznymi aspektami sprawowania prezydencji Rady Europejskiej i Rady do Spraw Zagranicznych - zgodnie z postanowieniami traktatu. W tych kwestiach prowadzone będą ścisłe konsultacje między prezydencją a (wybranym) przewodniczącym Rady Europejskiej i (mianowanym) wysokim przedstawicielem Unii do spraw zagranicznych i polityki bezpieczeństwa.

\section{OŚWIADCZENIE RADY EUROPEJSKIEJ. TRAKTAT Z LIZBONY - ŚRODKI PRZEJŚCIOWE DOTYCZĄCE SKLADU PARLAMENTU EUROPEJSKIEGO}

Jeżeli traktat z Lizbony wejdzie w życie po wyborach do Parlamentu Europejskiego zaplanowanych na czerwiec 2009 roku, jak najszybciej przyjęte zostaną środki przejściowe - zgodnie z koniecznymi procedurami prawnymi - by do końca kadencji 2009-2014 zwiększyć - zgodnie z liczbami przedstawionymi w ramach konferencji międzyrządowej, która zatwierdziła traktat z Lizbony - liczbę posłów do Parlamentu Europejskiego z dwunastu państw członkowskich, którym przyznano taką większą 
liczbę. W związku z tym do końca kadencji 2009-2014 całkowita liczba posłów do Parlamentu Europejskiego wzrośnie z 736 do 754 . Należy dążyć do tego, by zmiana ta weszła w życie, o ile to możliwe, w roku 2010.

\section{OŚWIADCZENIE RADY EUROPEJSKIEJ. TRAKTAT Z LIZBONY - MIANOWANIE CZLONKÓW PRZYSZLEJ KOMISJI}

Rada Europejska postanawia, że proces mianowania członków przyszłej Komisjia zwłaszcza jej przewodniczącego - rozpocznie się niezwłocznie po wyborach do Parlamentu Europejskiego zaplanowanych na czerwiec 2009 roku.

\section{Zalącznik 2}

\section{OŚWIADCZENIE RADY EUROPEJSKIEJ W SPRAWIE WZMOCNIENIA EUROPEJSKIEJ POLITYKI BEZPIECZEŃSTWA I OBRONY}

1. Od dziesięciu lat Unia Europejska jest uznanym podmiotem w globalnej polityce. Wzięła na siebie rosnące zobowiązania, na co wskazują jej coraz bardziej ambitne i zróżnicowane misje cywilne i wojskowe w służbie skutecznego multilateralizmu i pokoju.

2. Działania Unii nadal opierają się na wspólnej analizie zagrożeń i ryzyka, które mają wpływ na wspólne interesy Europejczyków. W związku z tym Rada Europejska przychyla się do analizy przedstawionej przez Sekretarza Generalnego/Wysokiego Przedstawiciela, we współpracy z Komisją, w dokumencie, w którym ponownie przeanalizowano realizację strategii bezpieczeństwa z 2003 roku, by ją usprawnić i uzupełnić o nowe elementy. Dokument ten pokazuje, że zagrożenia rozpoznane w 2003 roku są wciąż aktualne, ale również pojawiły się nowe rodzaje ryzyka, które mogą zagrozić bezpośrednio lub pośrednio bezpieczeństwu UE i którym musi ona sprostać we wszelkich aspektach.

3. By zmierzyć się z tymi wyzwaniami, Rada Europejska zamierza zaradzić niedostatkowi środków, którymi dysponuje Europa, zwiększając stopniowo jej potencjał cywilny i wojskowy. Wysiłek ten jest jednocześnie warunkiem, którego spełnienie ma pozwolić Europejczykom w wiarygodny i skuteczny sposób wywiązać się z ich obowiązków w ramach odnowionego partnerstwa transatlantyckiego; Rada Europejska potwierdza swoje zaangażowanie $\mathrm{w}$ to partnerstwo. $\mathrm{Z}$ tego względu przyłącza się do oświadczenia w sprawie zdolności przyjętego przez Radę, w którym ustanowiono konkretne i wymierne cele, tak by w najbliższych latach UE była w stanie prowadzić jednocześnie poza swoim terytorium wiele operacji cywilnych i wojskowych o różnej skali zgodnie z najbardziej prawdopodobnymi scenariuszami ${ }^{1}$.

1 W najbliższych latach Europa będzie musiała być przygotowana do tego, by - zgodnie z ustalonym zalożeniem, zakładającym rozmieszczenie w miejscu konfliktu 60000 żolnierzy w ciagu 60 dniu w przypadku poważniejszej operacji - w ramach różnorakich operacji przewidzianych w celu podstawowym $2010 \mathrm{i}$ w cywilnym celu podstawowym 2010 zaplanować i przeprowadzić jednocześnie 
4. Taki odnowiony cel wymaga zaangażowania, by rozwijać zdolności, z naciskiem na potencjał działania, elastyczność i interoperacyjność. Do ich realizacji konieczne są, na zasadzie dobrowolności, innowacyjne działania w zakresie specjalizacji, łączenia zasobów oraz wspólnego prowadzenia dużych projektów dotyczących sprzętu, przede wszystkim w zakresie planowania, zarządzania kryzysowego, przestrzeni kosmicznej i bezpieczeństwa morskiego. Z tego względu oświadczenie w sprawie zdolności opisuje wiele konkretnych projektów w kluczowych sektorach. Rada Europejska wyraża determinację we wspieraniu tych wysiłków w dłuższym okresie i apeluje do państw członkowskich o przełożenie tych zobowiązań na krajowe wymogi w zakresie sprzętu.

5. Strategiczną i gospodarczą koniecznością jest restrukturyzacja przemysłowego i technologicznego zaplecza europejskiej obrony, w szczególności w oparciu o europejskie centra doskonałości, tak by zapewnić jej trwałość i konkurencyjność; należy przy tym unikać zbędnych działań. Restrukturyzacja ta wymaga wzmocnienia mechanizmów ładu korporacyjnego, większego wysiłku w dziedzinie badań i technologii, a także zdynamizowania europejskiego rynku uzbrojenia. Z tego względu Rada Europejska wzywa do szybkiego zakończenia prac nad dyrektywą w sprawie wewnątrzwspólnotowego transferu sprzętu obronnego i dyrektywą w sprawie zamówień publicznych w dziedzinie obronności. Rada Europejska popiera również decyzję o rozpoczęciu realizacji inicjatywy, inspirowanej programem Erasmus, która ma ułatwić wymianę młodych oficerów w Europie.

6. Rada Europejska wspiera działania Sekretarza Generalnego/Wysokiego Przedstawiciela, które mają doprowadzić do utworzenia nowej jednolitej cywilno-wojskowej struktury strategicznego planowania operacji i misji EPBiO.

7. Rada Europejska zaznacza, że Unia jest zdecydowana dalej wspierać Organizację Narodów Zjednoczonych oraz wspierać wysiłki regionalnych organizacji bezpieczeństwa, w tym Unii Afrykańskiej, na rzecz promowania międzynarodowego pokoju i bezpieczeństwa. Potwierdza również cel zakładający wzmocnienie strategicznego partnerstwa między UE a NATO, tak by było ono zdolne stawić czoła aktualnym potrzebom, w duchu wzajemnego wzmacniania i poszanowania autonomii decyzyjnej. $Z$ tego względu popiera utworzenie nieformalnej grupy wysokiego szczebla UE-NATO,

- dwie ważne operacje na rzecz stabilizacji i odbudowy, angażujące odpowiednią liczbę personelu cywilnego wspieranego przez nie więcej niż 10000 żołnierzy w okresie co najmniej dwóch lat;

- dwie operacje szybkiego reagowania o ograniczonym czasie trwania, z wykorzystaniem w szczególności grup bojowych UE;

- operację pilnej ewakuacji obywateli europejskich (w mniej niż $10 \mathrm{dni}$ ), z uwzględnieniem podstawowej roli, jaką każde państwo odgrywa w odniesieniu do swoich obywateli, i z wykorzystaniem koncepcji państwa przewodniego w kwestiach konsularnych;

- misję obserwacyjną związaną z zakazem żeglugi lub zakazem lotów;

- cywilno-wojskową operację pomocy humanitarnej trwającą do $90 \mathrm{dni}$;

- kilkanaście cywilnych misji EPBiO (np. misji policyjnych, misji w zakresie praworządności, administracji cywilnej, ochrony ludności, reformy sektora bezpieczeństwa lub misji obserwacyjnych) o różnym charakterze - także w sytuacji, w której konieczne jest szybkie reagowanie - w tym jedną większą misję (licząca do 3000 ekspertów), która mogłaby trwać kilka lat.

Prowadząc te operacje i misje Unia Europejska wykorzystuje, w odpowiedni sposób i zgodnie z własnymi procedurami, środki i zdolności państw członkowskich, Unii Europejskiej, a w stosownym przypadku w ramach swoich operacji wojskowych - środki i zdolności NATO. 
by w sposób pragmatyczny usprawnić współpracę między obiema organizacjami w terenie. Powtarza, że istnieje konieczność pełnego zbadania uzgodnionej możliwości włączenia do EPBiO europejskich sojuszników UE niebędących jej członkami, z poszanowaniem procedur unijnych.

8. Ponadto Rada Europejska zatwierdza oświadczenie w sprawie bezpieczeństwa międzynarodowego przyjęte przez Radę, która przyjmuje konkretne działania, by pomóc UE odgrywać aktywniejszą rolę w zwalczaniu terroryzmu, rozprzestrzeniania broni masowego rażenia, przestępczości zorganizowanej i ataków cybernetycznych. Zwraca się do Rady i państw członkowskich, by dzięki zastosowaniu właściwych polityk i instrumentów zapewniły jego konkretną realizację.

Konkluzje prezydencji - Bruksela, 11 i 12 grudnia 2008 r.

Zalącznik 3

\section{OŚWIADCZENIE RADY EUROPEJSKIEJ W SPRAWIE BLISKIEGO WSCHODU}

Bliskowschodni proces pokojowy pozostanie jednym z głównych priorytetów Unii Europejskiej w roku 2009. Sprawiedliwy, trwały i ogólny pokój jest pilnie potrzebny. UE dołoży wszelkich starań - tak praktycznie, jak i politycznie - aby kontynuować proces pokojowy w przyszłym roku w ścisłej współpracy ze swoimi międzynarodowymi partnerami, w szczególności z kwartetem, tak aby wypracować rozwiązanie konfliktu izraelsko-palestyńskiego w oparciu o pokojowe i bezpieczne wspótistnienie dwóch państw. UE będzie również wspierać rozmowy Izraela z Syrią i, o ile będzie to możliwe, $z$ Libanem. Rada Europejska z zadowoleniem przyjmuje wysiłki zmierzające do ożywienia arabskiej inicjatywy pokojowej (w tym pismo arabskich ministrów spraw zagranicznych do prezydenta-elekta Baracka Obamy) jako element kompleksowego rozwiązania pokojowego między Izraelem a resztą regionu. Apelujemy do nowego rządu Stanów Zjednoczonych o przyłączenie się do naszych działań, by uczynić bliskowschodni proces pokojowy pilnym i głównym priorytetem.

\section{Zalącznik 4}

\section{OŚWIADCZENIE RADY EUROPEJSKIEJ W SPRAWIE ZIMBABWE}

Rada Europejska wyraziła poważne zaniepokojenie pogorszeniem się sytuacji humanitarnej w Zimbabwe. Wezwała do natychmiastowego uwolnienia osób zatrzymanych bez prawa kontaktu, takich jak obrończyni praw człowieka Jestina Mukoko. Wezwała do bezzwłocznego umożliwienia świadczenia pomocy humanitarnej, w szczególności w związku z rozprzestrzenianiem się epidemii cholery. Bardziej niż kiedykolwiek wcześniej pożądane jest, by wszystkie legalne partie polityczne szybko wypracowały rozwiązanie sytuacji odzwierciedlające wyniki wyborów, które odbyły się w tym roku. 
Zalącznik 5

\section{OŚWIADCZENIE RADY EUROPEJSKIEJ W SPRAWIE SPORTU}

Rada Europejska uznaje znaczenie wartości związanych ze sportem, bardzo istotnych dla społeczeństwa europejskiego. Podkreśla konieczność uwzględnienia specyficznego charakteru sportu, a nie tylko jego wymiaru gospodarczego. Rada wyraża zadowolenie $\mathrm{z}$ rozpoczęcia konstruktywnego dialogu prowadzonego $\mathrm{w}$ ramach pierwszego europejskiego forum w sprawie sportu zorganizowanego przez Komisję Europejską. Rada wzywa do pogłębienia dialogu z Międzynarodowym Komitetem Olimpijskim i przedstawicielami świata sportu, w szczególności w kwestii równoległego kształcenia sportowego i ogólnego młodzieży.

ZALĄCZNIK 6

\section{WYKAZ DOKUMENTÓW REFERENCYJNYCH PRZEDSTAWIONYCH RADZIE EUROPEJSKIEJ}

- Sprawozdanie Sekretarza Generalnego/Wysokiego Przedstawiciela na temat wdrażania europejskiej strategii bezpieczeństwa (dok. 17104/08);

- Oświadczenie Rady z 8 grudnia 2008 r. w sprawie wzmocnienia zdolności europejskiej polityki bezpieczeństwa i obrony (dok. 16840/08);

- Oświadczenie Rady z 8 grudnia 2008 r. w sprawie umocnienia bezpieczeństwa międzynarodowego (dok. 16751/08);

- Konkluzje Rady z 8 grudnia 2008 r. w sprawie integracji Romów (dok. 15976/1/08 REV 1);

- Konkluzje Rady z 8 grudnia 2008 r. w sprawie zintegrowanej polityki morskiej (dok. 16503/1/08 REV 1);

- Konkluzje Rady z 8 grudnia 2008 r. w sprawie rozszerzenia (dok. 16981/08);

- Oświadczenie Parlamentu Europejskiego, Rady i Komisji z 22 października 2008 r. w sprawie partnerskiego procesu komunikacji poświęconej Europie (dok. 13712/08). 